\title{
A Review of Al Alloy Anodes for Al-Air Batteries in Neutral and Alkaline Aqueous Electrolytes
}

\author{
Pengfei $\mathrm{Wu}^{1} \cdot$ Shengan $\mathrm{Wu}^{1} \cdot$ Dan Sun ${ }^{1} \cdot$ Yougen Tang ${ }^{1} \cdot$ Haiyan Wang ${ }^{1}$
}

Received: 17 June 2020 / Revised: 30 July 2020 / Accepted: 25 August 2020 / Published online: 2 November 2020

(C) The Chinese Society for Metals (CSM) and Springer-Verlag GmbH Germany, part of Springer Nature 2020

\begin{abstract}
Aluminum-air (Al-air) batteries are promising candidates for energy storage applications because of their high theoretical energy density and low cost. Nevertheless, their developments have been severely hindered by multiple obstacles, among which the activation and self-corrosion inhibition of $\mathrm{Al}$ anode have been considered to be significant challenges. In neutral electrolytes, the main problem is the activation of $\mathrm{Al}$ anode, while the self-corrosion of $\mathrm{Al}$ anode becomes dominant in alkaline electrolytes. Considerable efforts have been devoted to overcoming the dilemma associated with the $\mathrm{Al}$ anode. This review firstly underscores the underlying mechanisms of passivation and self-corrosion of $\mathrm{Al}$ anode in different electrolytes. Then, specific attentions are paid to $\mathrm{Al}$ alloy anode, including the role of various elements and standard processing technology. Finally, general conclusions, current limitations, and future perspectives on $\mathrm{Al}$ alloy anode are presented.
\end{abstract}

Keywords $\mathrm{Al}$-air battery $\cdot \mathrm{Al}$ alloy $\cdot$ Electrolyte $\cdot$ Corrosion inhibition $\cdot$ Activation

\section{Introduction}

With increasing energy demands, battery systems have attracted widespread attention as important power sources to ease this energy crisis [1-3]. Metal-air batteries (metal for $\mathrm{Al}, \mathrm{Zn}, \mathrm{Mg}$, etc.) have been rapidly developed because of their high energy density and low cost. Among the various metal-air batteries, Al-air battery has demonstrated great potential owing to its outstanding advantages, such as high specific capacity (2980 $\mathrm{Ah} \mathrm{kg}^{-1}$ ) [4], sufficient raw materials and geological abundance [5], low cost [6], environmentally benign, rapid mechanical rechargeability and so on.

In a typical prototype, the aqueous $\mathrm{Al}$-air battery consists of $\mathrm{Al}$ metal anode, air cathode, and aqueous electrolyte [7]. For air cathode, it is of great importance to develop low-cost oxygen reduction catalysts with high activity [8-13]. For $\mathrm{Al}$ anode, it is suffering from two main issues associating with the electrolyte. In neutral electrolytes, the passivation

Available online at https://link.springer.com/journal/40195.

Dan Sun

sundan4330@csu.edu.cn

1 Hunan Provincial Key Laboratory of Chemical Power Sources, College of Chemistry and Chemical Engineering, Central South University, Changsha 410083, China film on the surface of $\mathrm{Al}$ will reduce the anode reactivity and jeopardize the electrochemical performance of a battery. Alkaline electrolytes ( $\mathrm{KOH}$ or $\mathrm{NaOH})$ are always adopted to eliminate the passivation layer on the $\mathrm{Al}$ anode surface, while the $\mathrm{Al}$ anode is subjected to serious self-corrosion during both open-circuit state and discharge process, which sharply curtails the operating and shelf life of alkaline Al-air batteries $[14,15]$. To solve these problems, mitigation methods have been proposed including negative electrode alloying [16], electrolyte additives (inorganic [17], organic [18], complex [19], surfactant [20], natural compound [21]), solid-state electrolytes [22], nonaqueous electrolytes [23], and oil displacement under a nonworking state [24].

The preparation of $\mathrm{Al}$ alloy anodes has been investigated to improve the performance of the anode in Al-air battery [25]. Research has focused on finding alloying elements to enhance the activity while inhibiting the self-corrosion reaction. An ideal $\mathrm{Al}$ alloy should be capable of maintaining the electrochemical activity and suppressing self-corrosion simultaneously. Besides, the low-cost Al alloy can replace the high-cost high-purity $\mathrm{Al}$, which makes it possible to achieve the widespread use of Al-air battery. Developing multielement alloys combining advantages of multiple elements is a direction to achieve desired effects.

Corrosion inhibition and activation can be effectively improved by alloying different elements [26, 27]. Since 
$\mathrm{Al}$-air batteries have various problems in neutral and alkaline electrolytes, the performances of the prepared alloys in these two types of electrolytes are different. For example, even though $\mathrm{Al}$ alloys with high reactivity are suitable in neutral electrolytes, they suffer from the sharply accelerated self-corrosion and impaired discharge performance in alkaline electrolytes. Under this circumstance, adding some elements to $\mathrm{Al}$ is a feasible option to inhibit corrosion effectively. On the contrary, alloys that can cope with the low anode utilization in alkaline electrolytes may have too low operating voltage and current density to meet practical applications when discharged in neutral electrolytes.

In addition, due to a series of uncontrollable phenomena, such as shrinkage, segregation, and defects, the surface structure of $\mathrm{Al}$ alloy is nonuniform. Consequently, the uneven corrosion reaction of $\mathrm{Al}$ will occur on the surface of Al. The local corrosion will be aggravated, and other phenomena seriously affecting the electrochemical performance of the battery will happen. Therefore, many researchers re-integrated the structure of $\mathrm{Al}$ alloy by heat treatment, melt-spinning, rolling, and other post-processing processes to change the distribution state of added elements in the alloy, ultimately improving the electrochemical properties of Al alloy.

Although several recent reviews summarized the developments of Al-air battery, it is still required to explore further in terms of $\mathrm{Al}$ anodes [28]. Compared with other reviews, this review therefore focuses, especially on the failure mechanism and corresponding modification strategies of $\mathrm{Al}$ alloy anode. Definitely, the activation/corrosion inhibition mechanism models of $\mathrm{Al}$ are presented firstly. And then, the developments of $\mathrm{Al}$ alloy are introduced in detail based on the effects of various alloy elements. Moreover, we focus on the recent works of $\mathrm{Al}$ alloy processing technology that aims to improve the electrochemical performance of $\mathrm{Al}$ alloy.

\section{Mechanism}

\subsection{Reaction Mechanism}

Thermodynamically, $\mathrm{Al}$ exhibits a relatively negative electrode potential, which is $-1.66 \mathrm{~V}$ (vs. $\mathrm{Hg} / \mathrm{HgO}$ ) in saline and $-2.35 \mathrm{~V}$ (vs. $\mathrm{Hg} / \mathrm{HgO}$ ) in alkaline solution, as shown in Eqs. (1) and (2), respectively [29]:

$\mathrm{Al}_{(\mathrm{aq})}^{3+}+3 e^{-}=\mathrm{Al}_{(\mathrm{s})} \quad E=-1.66 \mathrm{~V}(\mathrm{vs} . \mathrm{Hg} / \mathrm{HgO})$,

$\mathrm{Al}(\mathrm{OH})_{4}^{-}+3 e^{-}=\mathrm{Al}_{(\mathrm{s})}+4 \mathrm{OH}^{-} \quad E=-2.35 \mathrm{~V}(\mathrm{vs} . \mathrm{Hg} / \mathrm{HgO})$.

In practice, the open-circuit potential of $\mathrm{Al}$ cannot reach theoretical value, because there are complicated electrode reaction processes on the $\mathrm{Al}$ surface [30]: (1) the formation and/or dissolution of the initial $\mathrm{Al}_{2} \mathrm{O}_{3}$ and subsequent $\mathrm{Al}(\mathrm{OH})_{3}$ layer; (2) three-electron charge transfer yielding $\mathrm{Al}^{3+}$ species; (3) the formation of corrosion products, $\mathrm{Al}(\mathrm{OH})_{4}^{-}$and $\mathrm{Al}(\mathrm{OH})_{3}$, as well as hydrogen evolution along with $\mathrm{Al}$ corrosion at electrolyte/electrode interface.

During the discharge process, the $\mathrm{Al}$ anode releases electrons and dissolves into electrolytes to become $\mathrm{Al}(\mathrm{OH})_{4}^{-}$and $\mathrm{Al}(\mathrm{OH})_{3}[31]$ :

$4 \mathrm{OH}^{-}+\mathrm{Al} \rightarrow \mathrm{Al}(\mathrm{OH})_{4}^{-}+4 e^{-} \quad E_{\mathrm{a}}=-2.35 \mathrm{~V}($ vs. $\mathrm{Hg} / \mathrm{HgO})$,

$\mathrm{Al}(\mathrm{OH})_{4}^{-} \rightarrow \mathrm{Al}(\mathrm{OH})_{3} \downarrow+\mathrm{OH}^{-}$.

Simultaneously, oxygen molecules diffuse through the gas diffusion layer and then receives electrons to form $\mathrm{OH}^{-}$on the electrolyte/electrode interface:

$\mathrm{O}_{2}+2 \mathrm{H}_{2} \mathrm{O}+4 e^{-} \rightarrow 4 \mathrm{OH}^{-} \quad E_{\mathrm{c}}=0.38 \mathrm{~V}$ (vs. $\mathrm{Hg} / \mathrm{HgO}$ ).

The overall reaction equation of the battery is [32]:

$4 \mathrm{Al}+3 \mathrm{O}_{2}+6 \mathrm{H}_{2} \mathrm{O} \rightarrow 4 \mathrm{Al}(\mathrm{OH})_{3} \downarrow \quad E_{\text {cell }}=2.73 \mathrm{~V}$.

In the case of open circuit and discharge, there will be a parasitic corrosion reaction competing with discharge reactions on the $\mathrm{Al}$ surface:

$2 \mathrm{Al}+6 \mathrm{H}_{2} \mathrm{O} \rightarrow 2 \mathrm{Al}(\mathrm{OH})_{3} \downarrow+2 \mathrm{H}_{2} \uparrow$.

There are two significant issues required to be concerned: (1) the formation of a passive oxide film that hinders the dissolution of $\mathrm{Al}$ and shifts the potential to a positive value; (2) the parasitic corrosion reaction of $\mathrm{Al}$ caused by the reduction of water during open-circuit and discharge will significantly reduce the utilization rate. In neutral electrolytes, the operating potential of $\mathrm{Al}$ electrode shifts positively (approximately $-0.8 \mathrm{~V}$ vs. SCE) due to the presence of the passive oxide film on $\mathrm{Al}$ surface. The $\mathrm{Al}$ anode still suffers from a severe self-corrosion because the electrode potential of $\mathrm{Al}$ anode is more negative in alkaline electrolytes, and the $\mathrm{Al}$ oxide film on the surface of alloy can be removed rapidly. These problems seriously restrict the development and practical application of Al-air battery. Therefore, more and more attentions have been paid to enhancing anode activation and suppressing self-corrosion.

\subsection{Activation Mechanism}

As mentioned earlier, the compact oxide layer can form spontaneously on the surface when the $\mathrm{Al}$ anode is immersed in the aqueous neutral electrolytes. This passive layer, nevertheless, is not conducive to the anode activation, which triggers a series of studies diving into the activation mechanisms. 


\subsubsection{The "Field Stimulate" Mechanism}

The earliest $\mathrm{Al}$ anode activation mechanism is the "field stimulate" mechanism proposed by Dražić [33]. The cross section of the interface is demonstrated in Fig. 1. With the absence of any adsorption, the negatively charged alloy surface opposes the transport of either $\mathrm{Al}$ ions to the electrolyte or the oxygen-containing anions to alloy. On the contrary, when anions such as $\mathrm{Cl}^{-}$are adsorbed on the surface of the alloy, the electric field is reversed and changes from opposing ion transport to simulating ion transport. This mechanism explains the activation of pure $\mathrm{Al}$ anode to a certain extent, but it does not indicate the role of alloying elements in the $\mathrm{Al}$ activation process.

\subsubsection{The "Dissolution-Redeposition" Mechanism}

The "dissolution-redeposition" mechanism proposed by Reboul in 1984 is accepted mostly [34]. As we can see from Fig. 2, during the reaction process, the alloy elements in the $\mathrm{Al}$ matrix are dissolved and oxidized together with $\mathrm{Al}$, generating cations in the electrolyte. The generated cations redeposit back onto the $\mathrm{Al}$ surface via electrochemical exchange with $\mathrm{Al}$, and simultaneously the compact oxide layer is partially broken to activate the Al. This mechanism
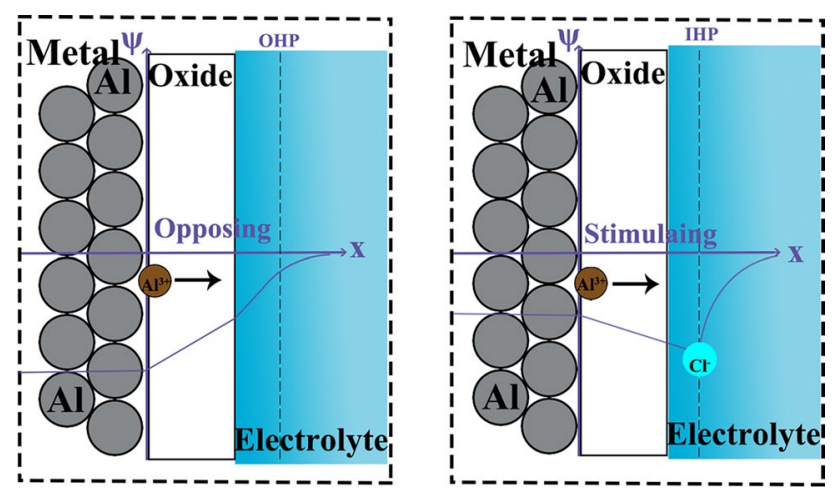

Fig. 1 The "field stimulate" mechanism explains the activation of a single element, but it does not work in terms of the synergy effects between elements.

\subsubsection{The "Eutectic" Mechanism}

In order to improve the overall performance of multi-element alloys, elements that can form low-temperature eutectic should be given priority. As presented in Fig. 3, the formed eutectic on the $\mathrm{Al}$ surface can give rise to separated oxide film, active sites for alloy dissolution and enhanced adsorption of anions such as chloride ions that cause pitting corrosion by forming soluble complexes with cations [35]. It is not difficult to conclude that the key to activation is controlling the amount of these amalgam and other forms of eutectics on the surface of the Al matrix. To achieve this purpose, studies on changing the structure of the $\mathrm{Al}$ alloy have been extensively performed.

\subsection{Corrosion Inhibition Mechanism}

The corrosion mechanisms of $\mathrm{Al}$ have been thoroughly studied whether in a salt solution for the cathodic protection or alkaline solution related to nuclear energy engineering $[16,36,37]$. Self-corrosion reaction is detrimental to the $\mathrm{Al}$ anode utilization, thus corrosion inhibition mechanism has been investigated particularly. To date, various $\mathrm{Al}$ alloy anodes have been proposed for Al-air battery. The working mechanism of suppressing the self-corrosion of proposed alloys are as follows: (1) To increase the hydrogen evolution overpotential of $\mathrm{Al}$ anode, alloying $\mathrm{Al}$ with elements possessing high hydrogen evolution overpotential (i.e., Sn, $\mathrm{Zn}$ and $\mathrm{In}$ ) is one of the essential corrosion inhibition methods [38]; (2) Stabilizing the Al oxide film or forming a new protective film to inhibit corrosion [i.e., $\mathrm{Zn}(\mathrm{OH})_{2}, \mathrm{In}(\mathrm{OH})_{3}$ and $\mathrm{In}_{2} \mathrm{O}_{3}$ ], because the oxide film can prevent direct contact between the $\mathrm{Al}$ anode and the electrolyte [39]; (3) Adding elements (i.e., $\mathrm{Mg}$ ) with electrode potentials more negative than $\mathrm{Al}$ to protect $\mathrm{Al}$ matrix by forming a galvanic-couple [40]; (5) Forming eutectics by including impurity elements in the eutectics can improve the alloy's tolerance for
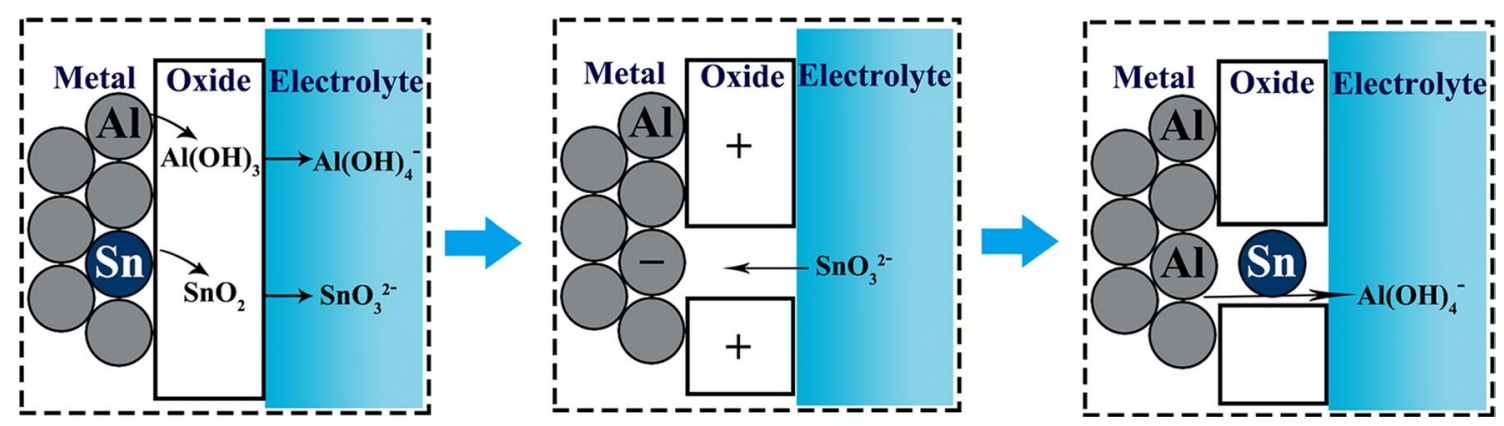

Fig. 2 The "dissolution-redeposition” mechanism. Reproduced with permission from Ref. [51]. Copyright 2013, Elsevier B.V 

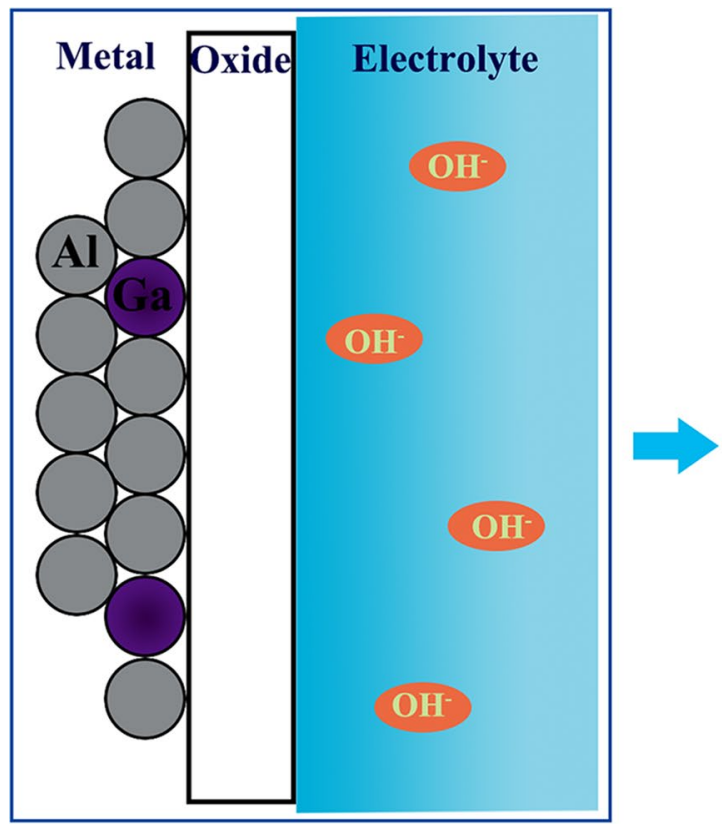

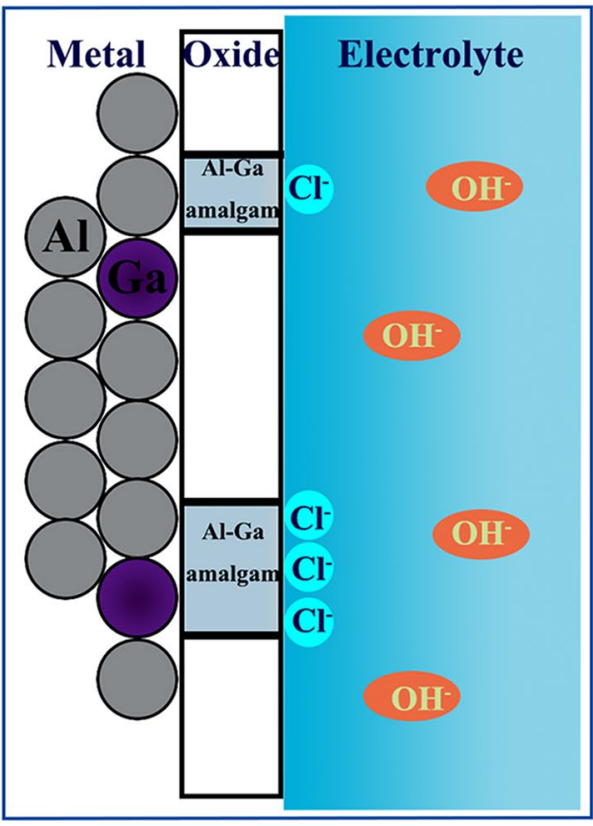

Fig. 3 The "eutectic" mechanism

impurities; (6) Second-phase precipitation by excess alloying elements acts as cathodic centers for the hydrogen evolution reaction [41, 42]. The uniform precipitate of the second phase is also an excellent method to reduce local corrosion. The work mechanisms of various alloying elements are summarized as the following.

\section{Improvement Strategy}

\subsection{Alloying Elements}

The choice of alloying element mainly has made based on the following principles: (1) They are endowed with solid solubility in Al matrix to avoid large amounts of precipitation in the grain boundary. Therefore, it will not cause severe local corrosion on $\mathrm{Al}$ surface [43]; (2) Their introduction can break the compact oxide film of $\mathrm{Al}$, resulting in the reduced resistance of the oxide film and the extended battery operating voltage [44]; (3) They have a lower melting point, which means that they can melt into the pores and cracks of the passive film at the battery operating temperature, thereby promoting the destruction of the passive film [45]; (4) The as-formed anions have enough solubility in the electrolyte [46]. In general, alloying elements can activate $\mathrm{Al}$ by the mechanism of "dissolution and redeposition" [30]; (5) Due to their high hydrogen evolution overpotential, the hydrogen evolution reaction of $\mathrm{Al}$ alloy is inhibited, improving the utilization rate of the anode [47]. In the following content, the role of various elements will be introduced comprehensively.

\subsubsection{Sn}

Sn mainly serves to activate Al through the "dissolution-redeposition" mechanism. After $\mathrm{Al}$ and $\mathrm{Sn}$ dissolving into the electrolyte, $\mathrm{Sn}$ will be oxidized to $\mathrm{SnO}_{3}^{2-}$. As illustrated in Fig. 2, the $\mathrm{SnO}_{3}^{2-}$ was ultimately reduced to $\mathrm{Sn}$ to deposit on the Al surface via reacting with Al. This phenomenon results in the local breakdown of oxide film and subsequent local dissolution of the Al matrix. Additionally, Sn can form low-temperature eutectic with elements such as $\mathrm{Mg}, \mathrm{Ga}$, and In, as active sites on the surface of $\mathrm{Al}$ matrix. According to Ren et al. [48], the corrosion surfaces of Al-Sn and $\mathrm{Al}-\mathrm{Mg}-\mathrm{Sn}$ alloys were measured by a $3 \mathrm{D}$-measuring laser microscope (MLM), as shown in Fig. $4 a$ and b, the maximum corrosion depths measured for the two alloys are 408.55 and $196.26 \mathrm{~mm}$, respectively. The Al-Mg-Sn alloy with $\mathrm{Sn}-\mathrm{Mg}$ inclusions demonstrates the most negative open-circuit potential. Similarly, the open-circuit potential of the Al-Sn alloy also negative shift slightly compared with pure $\mathrm{Al}$ (Fig. 4c), and the corrosion potential is close to the open-circuit potential (Fig. 4d). Apart from that, Sn with a high hydrogen evolution overpotential can stabilize the oxide film on the Al surface $[49,50]$. In the borate buffer solution with $\mathrm{pH}=7.8$, the resistance of the anodic oxide film of the high purity $\mathrm{Al}$ is $48.13 \mathrm{k} \Omega \mathrm{cm}^{2}$, and the $\mathrm{Al}-0.02 \mathrm{wt} \% \mathrm{Sn}$ and $\mathrm{Al}-0.40 \mathrm{wt} \% \mathrm{Sn}$ alloy is 49.11 and $69.66 \mathrm{k} \Omega \mathrm{cm}^{2}$, respectively, meaning the enhanced self-corrosion resistance. However, it should be noted that the maximum solid solubility of $\mathrm{Sn}$ in the $\mathrm{Al}$ matrix is only $0.12 \mathrm{wt} \%$ [51]. When the total quantity surpasses the solubility limit, Sn will precipitate 

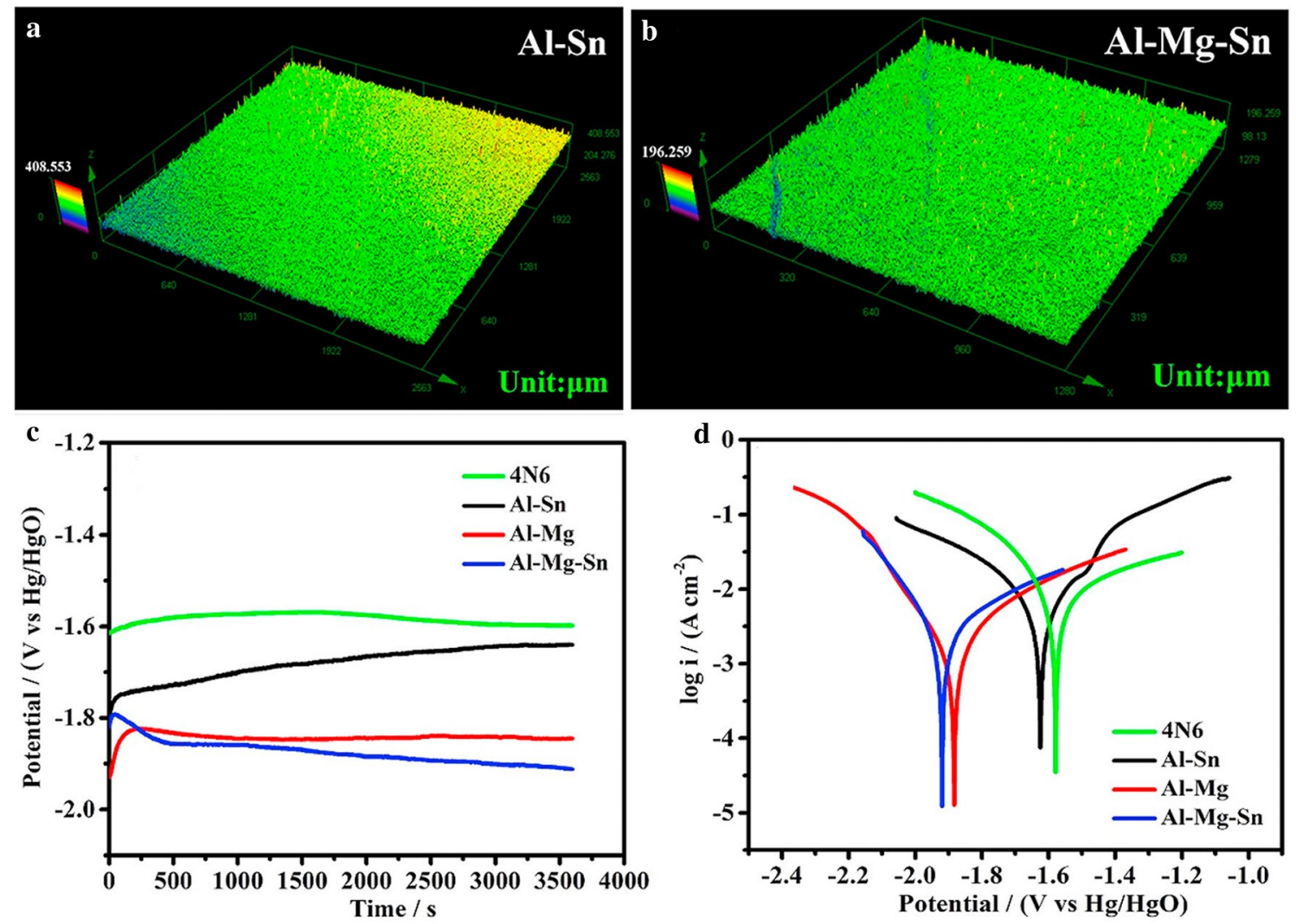

Fig. 4 Typical 3D-MLM images of the corroded surface of a Al-Sn, b Al-Mg-Sn alloys, $\mathbf{c}$ open-circuit potential (OCP) curves, $\mathbf{d}$ Tafel plots of the pure $\mathrm{Al}(4 \mathrm{~N} 6), \mathrm{Al}-\mathrm{Mg}, \mathrm{Al}-\mathrm{Sn}, \mathrm{Al}-\mathrm{Mg}-\mathrm{Sn}$ alloys. Reproduced with permission from Ref.[48]. Copyright 2019, Elsevier B.V

along the grain boundaries and intermetallic zones to form a second phase as corrosion initiation, promoting local corrosion on the $\mathrm{Al}$ surface.

\subsubsection{Zn}

Zn with a high overpotential of hydrogen evolution reaction can promote the alloying of other elements to form active sites for alloy dissolution uniformly on the surface of the $\mathrm{Al}$ matrix. Therefore, $\mathrm{Zn}$ plays an important role in both corrosion inhibition and activation of $\mathrm{Al}$ [52]. Tang et al. [53] proposed that $\mathrm{Zn}$ promoted the alloying of In with $\mathrm{Al}$, and the In-enriched phase uniformly distributed on the surface of the $\mathrm{Al}$ matrix, forming the active sites for alloy dissolution. In $4 \mathrm{M} \mathrm{NaOH}$ solution, the corrosive potential of the Al-0.10 wt $\%$ In-3.48 wt $\%$ Zn alloy shifted negatively by $70 \mathrm{mV}$ compared with pure $\mathrm{Al}$. Besides, $\mathrm{Zn}$ can suppress the hydrogen evolution by forming a $\mathrm{Zn}(\mathrm{OH})_{2}$ layer on the alloy surface, which obstructs the direct contact between the alloy and electrolyte. However, $\mathrm{Zn}$ is poorly soluble in the Al matrix (approximately $3 \mathrm{wt} \%$ ) [54]. When excessive $\mathrm{Zn}$ is added, a large number of segregation phases will form, which becomes the origin of self-corrosion. Thus, in $4 \mathrm{M} \mathrm{NaOH}$ solution, the hydrogen evolution rate of the $\mathrm{Al}-0.10 \mathrm{wt} \% \mathrm{In}-3.48 \mathrm{wt} \% \mathrm{Zn}$ alloy is close to $0.01 \mathrm{~mL} \mathrm{mg}^{-1} \mathrm{~min}^{-1}$ of pure Al, while that of Al-0.22 wt $\%$ In-3.00 wt $\% \mathrm{Zn}$ alloy is only $0.001 \mathrm{~mL} \mathrm{mg}^{-1} \mathrm{~min}^{-1}$.

\subsubsection{Mg}

Ren et al. [48] compared the effects of $\mathrm{Mg}$ and $\mathrm{Sn}$ on $\mathrm{Al}$ alloy, indicating that both $\mathrm{Mg}$ and $\mathrm{Sn}$ can reduce the corrosion of $\mathrm{Al}$ alloy and significantly improve the electrochemical performance of the Al-air battery in alkaline electrolyte. Under the same condition $(4 \mathrm{M} \mathrm{NaOH}$ solution at a current density of $60 \mathrm{~mA} \mathrm{~cm}{ }^{2}$ ), $\mathrm{Mg}$ performs better than $\mathrm{Sn}$, and $\mathrm{Al}-\mathrm{Mg}$ alloy obtains the best specific capacity of $2723.7 \mathrm{mAh} \mathrm{g}^{-1}$. Sn activates the alloy by thinning the passivation film on the Al matrix surface. Moreover, Sn has a high hydrogen evolution overpotential than $\mathrm{Al}$, which can inhibit the corrosion of $\mathrm{Al}$ alloy. However, the alloying elements will be precipitated along the grain boundary to form a second phase at a certain temperature if the solid solubility limit in $\mathrm{Al}$ is exceeded, leading to the occurrence and spread of local corrosion. The experiment had proved that $\mathrm{Sn}$ tends to form a second phase on the surface of $\mathrm{Al}$ matrix, while Mg element hardly precipitates out. The reason is that the solid solubility of $\mathrm{Mg}$ in $\mathrm{Al}(10.7 \mathrm{wt} \%)$ is 
higher than that of $\mathrm{Sn}(0.12 \mathrm{wt} \%)$, and $\mathrm{Mg}$ distributes more uniformly than $\mathrm{Sn}$ in the $\mathrm{Al}$ alloy. Therefore, the addition of $\mathrm{Mg}$ avoids local corrosion caused by Sn. Additionally, Al is protected because of the galvanic couple formed by $\mathrm{Mg}$ with more negative potential than $\mathrm{Al}$. Accordingly, in $4 \mathrm{M}$ $\mathrm{KOH}$ solution, the effect of $\mathrm{Mg}$ element is better than that of $\mathrm{Sn}$. Moreover, the corrosion potential of $\mathrm{Al}-\mathrm{Mg}$ alloy is $-1.872 \mathrm{~V}$, which is more negative than $-1.625 \mathrm{~V}$ of $\mathrm{Al}-\mathrm{Sn}$ alloy. As a result, the anode utilization rate of $\mathrm{Al}-\mathrm{Mg}$ alloy $(91.4 \%)$ is higher than that of Al-Sn alloy (86.2\%).

\subsubsection{Ga}

The activation ability of $\mathrm{Ga}$ is better than most elements owning to its many advantages. Firstly, the melting point of $\mathrm{Ga}\left(29^{\circ} \mathrm{C}\right)$ is very low, which is conducive to the destruction of the passive film [55]. Secondly, the as-formed $\mathrm{HGaO}_{3}^{2-}$ and $\mathrm{GaO}_{2}^{-}$have good solubility in the aqueous electrolyte, significantly promoting the dissolution-redeposition process [46]. Thirdly, surface diffusion of the $\mathrm{Ga}-\mathrm{Al}$ amalgam compositing of $\mathrm{Ga}$ and $\mathrm{Al}$ facilitates the detachment of the passive film and the adsorption of chloride ions [56]. Therefore, adding $\mathrm{Ga}$ to $\mathrm{Al}$ alloy can get higher working voltage and better electrochemical performance in neutral electrolytes. However, in the alkaline electrolyte where the oxide film has been dissolved in a large amount, the activation ability of Ga will cause more severe corrosion instead. Sun et al. [57] confirmed this conclusion, as clearly illustrated in Fig. 5a-d, the corrosion of the Al-Ga alloy surface was much more severe than that of the other alloys in the $1 \mathrm{M} \mathrm{KOH}$ solution. Furthermore, According to Fig. 5e, the hydrogen evolution rate of Al-Ga alloy $\left(0.061 \mathrm{~mL} \mathrm{~cm}^{-2} \mathrm{~min}^{-1}\right)$ was much higher than that of pure $\mathrm{Al}\left(0.016 \mathrm{~mL} \mathrm{~cm}^{-2} \mathrm{~min}^{-1}\right)$. And charge transfer resistance decreased in the following order: Al-Sn > Al-In > pure Al > Al-Ga (Fig. 5f).

\section{1 .5 In}

In is mainly used for activation. In-rich inclusions formed by In with other alloying elements can make the nearby $\mathrm{Al}$ dissolve locally and then get the oxide film cracked. Eventually, the Al matrix can dissolve in a larger range [58]. Bessone et al. [59] revealed that In deposited on the surface of Al matrix to form In-Al amalgam, which could separate the oxide film and avoid re-passivation. However, compared with Ga, the activation ability of In is slightly inferior. There are two main reasons for the inferiority of In: (1) the content of In is limited by the solid solubility (about $0.13 \mathrm{wt} \%$ ) [51, 60]; (2) the formed $\mathrm{InO}_{2}^{-}$can be saturated quickly in the electrolyte, and excessive In will form $\mathrm{In}_{2} \mathrm{O}_{3}$ to cover alloy surface [46]. A passive layer will be formed subsequently, which leads to a decrease in activation performance. Ma et al. [61] tested the discharge performance of Al-air battery based on different alloys at current densities of $20 \mathrm{~mA} \mathrm{~cm}^{-2}$ for $5 \mathrm{~h}$ in $2 \mathrm{M} \mathrm{NaCl}$ solution, the $0.5 \mathrm{wt} \% \mathrm{Mg}-0.1 \mathrm{wt} \%$ $\mathrm{Sn}-0.02 \mathrm{wt} \% \mathrm{In}-\mathrm{Al}$ alloy's cell potential is $1.07 \mathrm{~V}$, which is much higher than the $0.23 \mathrm{~V}$ of $0.5 \mathrm{wt} \% \mathrm{Mg}-0.1 \mathrm{wt} \%$ $\mathrm{Sn}-0.02 \mathrm{wt} \% \mathrm{Ga}-\mathrm{Al}$ alloy. However, as shown in Fig. 5e, Ga, In significantly inhibit corrosion of $\mathrm{Al}$ alloys and the hydrogen evolution rate of $\mathrm{Al}-\mathrm{In}$ alloy $\left(0.006 \mathrm{~mL} \mathrm{~cm}^{-2} \mathrm{~min}^{-1}\right)$ is markedly lower than that of Al-Ga alloy due to the high hydrogen evolution overpotential of In in alkaline electrolytes [57]. Xiong et al. [62] added $0.05 \mathrm{wt} \%$ In to Al-0.5 wt\% Mg-0.08 wt\% Sn-0.05 wt\% Ga-Al alloy, which reduced the hydrogen evolution rate of the alloy from 0.2668 to $0.1941 \mathrm{~mL} \mathrm{~cm}^{-2} \mathrm{~min}^{-1}$ in $4 \mathrm{M} \mathrm{NaOH}$ solution. Meanwhile, the dissolution rate of the alloy in $4 \mathrm{M} \mathrm{NaCl}$ solution was accelerated, as proved by the growing corrosion current density from $7.7 \times 10^{-3}$ to $27.6 \times 10^{-3} \mathrm{~mA} \mathrm{~cm}^{-2}$.

\subsubsection{Mn}

Impurities of $\mathrm{Fe}$ in $\mathrm{Al}$ alloys can cause severe corrosion by forming the cathode center of the hydrogen evolution reaction. $\mathrm{Mn}$ element can form $(\mathrm{Mn}, \mathrm{Fe}) \mathrm{Al}_{6}$ phase with Fe element in $\mathrm{Al}$ alloy, and the $(\mathrm{Mn}, \mathrm{Fe}) \mathrm{Al}_{6}$ phase does not change the potential of the Al matrix. Hence, the introduction of Mn prevents the impurity $\mathrm{Fe}$ from forming the cathode center of the hydrogen evolution reaction and does not cause other side effects. Thus, the addition of $\mathrm{Mn}$ to $\mathrm{Al}$ alloy improves its impurity Fe intolerance [63].

\subsubsection{Ca}

The corrosion rate of the $\mathrm{Al}$ anode decreases with increasing $\mathrm{Ca}$ element addition, from $1320 \mathrm{~mm} \mathrm{a}^{-1}$ (millimeter per year) of without $\mathrm{Ca}$ to $1150 \mathrm{~mm} \mathrm{a}^{-1}$ of containing $1.140 \mathrm{wt} \%$ $\mathrm{Ca}$ in the 1-h corrosion test in $4 \mathrm{M} \mathrm{KOH}$ solution [64]. Because $\mathrm{Ca}$ can modify the microstructure of the $\mathrm{Al}$ anode significantly by forming Ca-rich phases such as $\mathrm{Al}_{4} \mathrm{Ca}$ and $\mathrm{Al}_{2} \mathrm{Ca}$, and the dendritic structure and grain size become finer with increasing $\mathrm{Ca}$ addition. Besides, $\mathrm{Ca}^{2+}$ ions can prevent the production of hydrogen on the $\mathrm{Al}$ alloy by the strong affinity to $\mathrm{OH}^{-}[65]$.

\subsubsection{Bi}

$\mathrm{Bi}$ can accelerate the dissolution of the $\mathrm{Al}$ matrix via microgalvanic effect since it induces the segregation phases that have a much more positive standard potential than Al substrate [66]. The segregation phases, thus, act as the cathodic sites in the galvanic microcells. So that in $2 \mathrm{M} \mathrm{NaCl}$ solution, the corrosion current density of the Al-0.15 wt\% $\mathrm{Bi}-0.15 \mathrm{wt} \% \mathrm{~Pb}\left(7.54 \times 10^{-3} \mathrm{~mA} \mathrm{~cm}^{-2}\right)$ is higher than that of the pure $\mathrm{Al}\left(2.58 \times 10^{-3} \mathrm{~mA} \mathrm{~cm}^{-2}\right)$. 

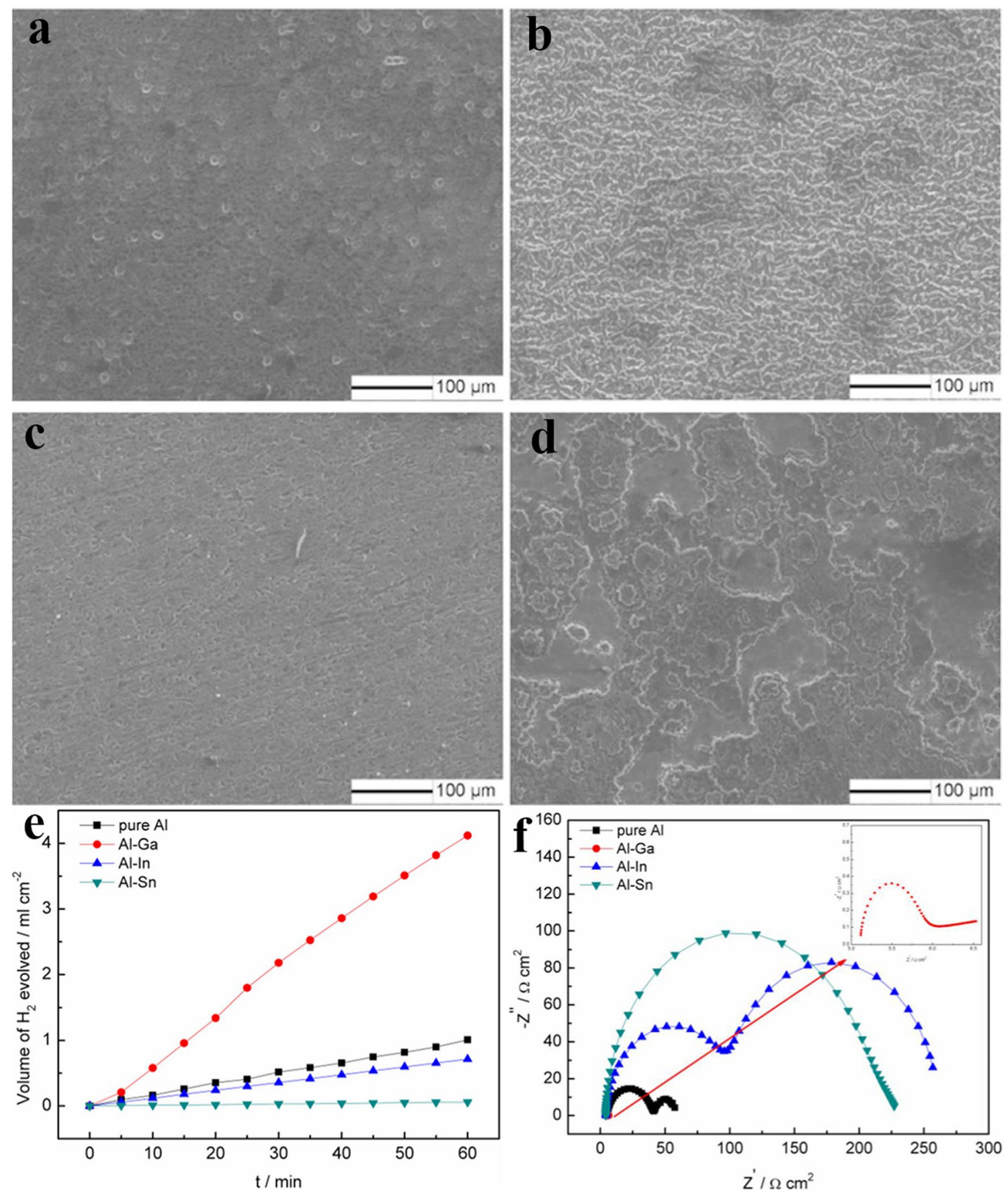

Fig. 5 Corrosion morphologies of a pure Al, b Al-Ga, c Al-In, d Al-Sn alloys immersed in $1 \mathrm{M} \mathrm{KOH}$ solutions for $1 \mathrm{~h}$ at OCP; hydrogen evolution rates e and electrochemical impedance spectroscopy plots $\mathbf{f}$ of pure Al, Al-Ga, Al-In, and Al-Sn alloys. Reproduced with permission from Ref.[57]. Copyright 2015, The Electrochemical Society

\subsubsection{Pb}

The $\mathrm{Pb}$ film at the Al-oxide surface has destabilizing effects on the Al oxide film synergistically with the chloride ions in the solution [67]. The addition of $\mathrm{Pb}$ element can effectively activate the Al alloy surface by making the passive film unstable and dissolve eventually [68].
The solubility of $\mathrm{Pb}$ in $\mathrm{Al}$ is very low [69]. As presented in Fig. 6a, after heat-treated for $1 \mathrm{~h}$ at $600{ }^{\circ} \mathrm{C}$, the corrosion potential of $\mathrm{Al}-0.1 \mathrm{wt} \% \mathrm{Ga}-0.005 \mathrm{wt} \% \mathrm{~Pb}$ alloy $(-0.97 \mathrm{~V})$ is higher than that of $\mathrm{Al}-0.1 \mathrm{wt} \% \mathrm{Ga}$ alloy $(-0.83 \mathrm{~V})$, which is attributed to the activation ability of $\mathrm{Pb}$ nanofilm and those nearly spherical particles formed on alloy surface [70]. 

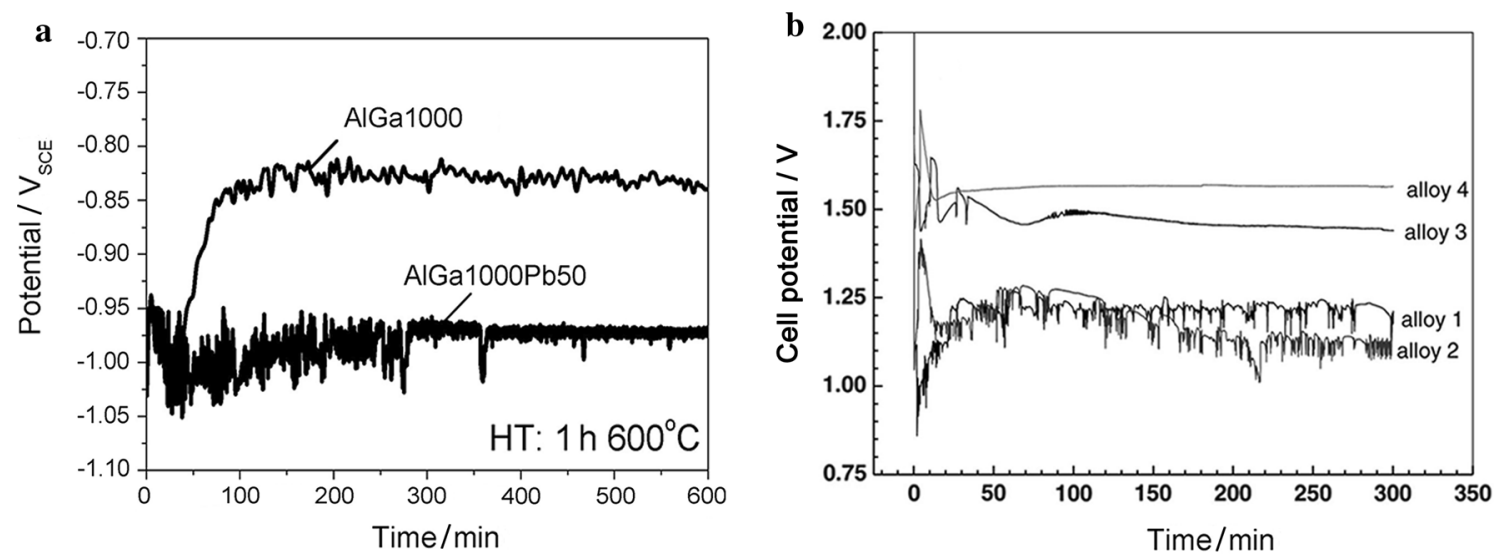

Fig. 6 a Corrosion potentials of alloys $\mathrm{Al}-0.1 \mathrm{Ga}-0.005 \mathrm{~Pb}, \mathrm{Al}-0.1 \mathrm{Ga}$ in acidified synthetic seawater (Reproduced with permission from Ref [70]. Copyright 2017, Elsevier Ltd.), b discharge behavior of Al-air battery based on alloy 1 (Al-0.5Mg-0.1Sn-0.02In), alloy 2 (Al-0.5Mg$0.1 \mathrm{Sn}-0.02 \mathrm{Ga}$ ), alloy $3(\mathrm{Al}-0.5 \mathrm{Mg}-0.1 \mathrm{Sn}-0.02 \mathrm{In}-0.1 \mathrm{Si})$, alloy $4(\mathrm{Al}-0.5 \mathrm{Mg}-0.1 \mathrm{Sn}-0.02 \mathrm{Ga}-0.1 \mathrm{Si})$ in $4 \mathrm{M} \mathrm{NaOH}$ solution at current densities of $20 \mathrm{~mA} \mathrm{~cm}^{-2}$ for $5 \mathrm{~h}$. Reproduced with permission from Ref.[61]. Copyright 2016, The Electrochemical Society

\subsubsection{Si}

Researchers found that adding Si element into Al alloy can promote the discharge performance of Al-air battery because $\mathrm{Si}$ could considerably reduce casting defects of $\mathrm{Al}$ alloy via enhancing the casting liquidity of $\mathrm{Al}$ alloy [71]. As shown in Fig. 6b, the addition of Si can make the cell potential higher and more stable [61].

\subsection{Post-processing Technology}

As mentioned above, the distribution of the alloy element plays a vital role in the performance of the alloy element. Promoting the formation of segregation phases on alloy surfaces by alloying elements is one of the most common purposes, which allows the elements to function to a great extent. On the other hand, excessive segregation phases will cause severe self-corrosion, which needs to be avoided by process technology. Moreover, the nonuniform corrosion caused by the local enrichment of alloying elements is also detrimental to anode performance. To address these issues, the researchers have proposed some post-processing technologies.

\subsubsection{Heat Treatment}

Zhang et al. [72] investigated the heat treatment of $\mathrm{Al}-\mathrm{Sb}$ alloy under different conditions. The $\mathrm{Al}-\mathrm{Sb}$ alloys were heat-treated at $550{ }^{\circ} \mathrm{C}$ for $3 \mathrm{~h}, 6 \mathrm{~h}$, and $9 \mathrm{~h}$, respectively, then quenched in water to obtain the experimental alloys. The specimens were ground, polished, and etched. Their microstructures were displayed in Fig. 7. There were several pits around the grain boundary of the as-cast Al- $0.02 \mathrm{wt} \% \mathrm{Sb}$ alloy (Fig. 7a). In terms of Al-0.02Sb alloy heat-treated for
$3 \mathrm{~h}$, the bright second phase particles (Al-Sb precipitates) distributed on the alloy surface around grain boundaries instead of deep pits (Fig. 7b). It indicated that heat treatment could promote the precipitation of $\mathrm{Al}-\mathrm{Sb}$ phase that inhibits the prior dissolution of grain boundary because of the high hydrogen evolution potential of $\mathrm{Sb}$ [51]. However, the excessive number of density and size of bright second phase particles gradually increased even precipitated in the grain interior with the prolonged time of heat treatment, and these made the local self-corrosion more serious (Fig. 7c, d). Hence, the utilization rate of anode was reduced. In the $\mathrm{Al}$-air battery performance test with different $\mathrm{Al}-\mathrm{Sb}$ alloys in $4 \mathrm{M} \mathrm{KOH}$ solution at $20 \mathrm{~mA} \mathrm{~cm}^{-2}$, the $\mathrm{Al}-0.02 \mathrm{wt} \% \mathrm{Sb}$ alloy under a heat treatment at $550{ }^{\circ} \mathrm{C}$ for $3 \mathrm{~h}$ exhibited the best anodic efficiency $92.6 \%$, superior to $87.5 \%$ of the Al-0.02 wt $\%$ Sb alloy as-cast. With the extension of heat treatment time, the anodic efficiency of the Al-0.02 wt\% $\mathrm{Sb}$ alloy with heat treatment at $550{ }^{\circ} \mathrm{C}$ for $6 \mathrm{~h}$ and $9 \mathrm{~h}$ was reduced to $91.6 \%$ and $86.4 \%$, respectively.

\subsubsection{Solution-Annealing Treatment}

The as-cast alloy was heated at $570{ }^{\circ} \mathrm{C}$ for $2 \mathrm{~h}$, and then quenched in water to room temperature to obtain the solution-annealed alloy. Solution-annealing treatment is also a way to improve the electrochemical properties of $\mathrm{Al}$ alloy via enlarging the grain boundary and increasing grain size to promote the formation of segregation phase [73]. Because active alloy elements $(\mathrm{Mg}, \mathrm{Sn}$, and $\mathrm{Ga}$ ) were involved, the activity of the alloy was significantly improved. Accordingly, the alloy after a solution-annealing treatment also suffers from severe corrosion. Based on the corrosion tests of the alloys immersed in $3 \mathrm{wt} \% \mathrm{NaCl}$ solutions for 21 days, the corrosion rate of the solution-annealed alloy was as high 

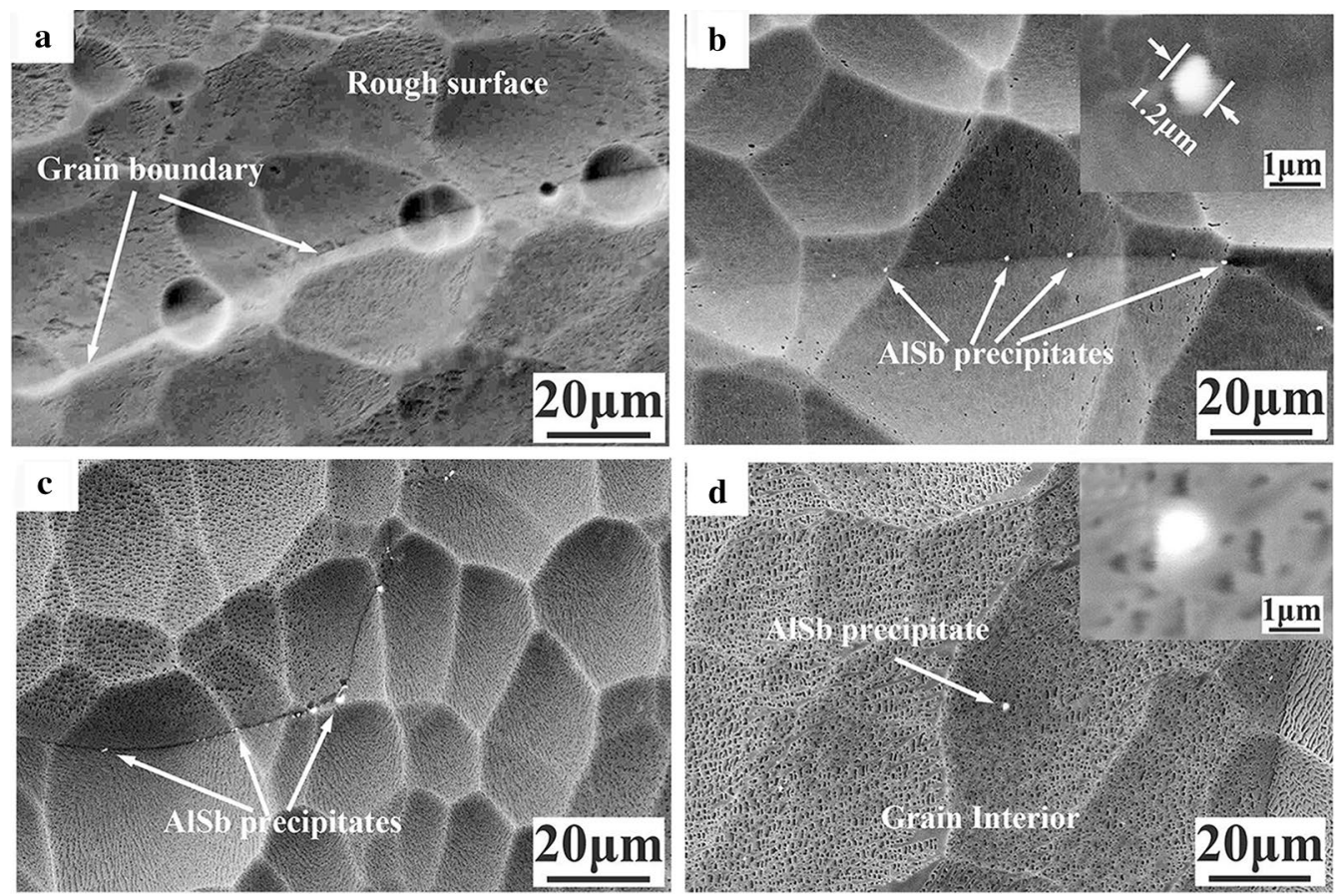

Fig. 7 Scanning electron microscope images of different alloys after discharge at $20 \mathrm{~mA} \mathrm{~cm}{ }^{-2}$ for $6 \mathrm{~h}$ : a the as-cast Al-0.02Sb alloy; $\mathbf{b}$ Al-

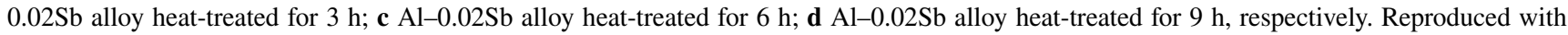
permission from Ref.[72]. Copyright 2019, ASM International

as $37.52 \mathrm{~mm} \mathrm{a}^{-1}$, far exceeding $21.03 \mathrm{~mm} \mathrm{a}^{-1}$ of the as-cast alloy and $0.01 \mathrm{~mm} \mathrm{a}^{-1}$ of the pure Al. Based on the above discussions, even though these methods can effectively improve the effect of alloy elements, serious self-corrosion still appears. This is because the alloy segregation phase is not only improving the effect of elements, but also the origin of corrosion. According to the practical applications, how to achieve an optimal balance should be taken into account.

\subsubsection{Rolling Processing}

Yin et al. [74] enlarged the grain boundary of Al alloy by rolling, but the resulting segregation phase was evenly distributed on the whole alloy surface. The as-cast alloy was melted at $750{ }^{\circ} \mathrm{C}$, and quenched in cold water $\left(20^{\circ} \mathrm{C}\right)$ after being homogenized at $500{ }^{\circ} \mathrm{C}$ for $6 \mathrm{~h}$. Finally, the experimental alloy was obtained after cold-rolled. As shown in Fig. 8a and b, compared with the as-cast alloy, the number of grain boundaries of the alloy after rolling-process optimization is significantly increased. This provided more channels for the anode reaction, thus promoting the activation of the anode and increasing the working voltage of a battery [75]. Additionally, the dendritic phases were present in the as-cast $\mathrm{Al}$ alloy, while the rolled $\mathrm{Al}$ alloy was the dispersion phases (Fig. 8c and d). The surface morphology of the homogeneous dispersion phases led to the uniform corrosion of the $\mathrm{Al}$ alloy. Compared with the as-cast alloy anode, the hydrogen evolution rate of the as-rolled alloy anode in $4 \mathrm{M} \mathrm{NaOH}$ solution declines from 0.265 to $0.1833 \mathrm{~mL} \mathrm{~cm}^{-2} \mathrm{~min}^{-1}$.

\subsubsection{Melt-Spinning}

By a single roller melt spinning technique with a NMS-II machine under an argon atmosphere, Ma et al. [46] prepared a rapidly solidified $\mathrm{Al}-\mathrm{Mg}-\mathrm{Sn}$ base alloy with the cast ingot. During the rapid solidification process of single roll meltspinning, some alloying elements dissolved in $\mathrm{Al}$ matrix to form a supersaturated solid solution. It reduced the precipitation of alloying elements along grain boundaries and made the $\mathrm{Al}$ anode changed from intergranular corrosion to uniformly intragranular corrosion in alkaline electrolyte, which was beneficial to the electrochemical performance of $\mathrm{Al}$ anode.

\section{Conclusions}

In recent years, Al-air batteries have been significantly developed in electrochemical performance and practical applications. As an essential composition, $\mathrm{Al}$ alloy anode materials have been widely investigated. In order to activate the $\mathrm{Al}$ alloy fully and reduce the self-corrosion as much as possible, adding other elements to form multiple alloys and 

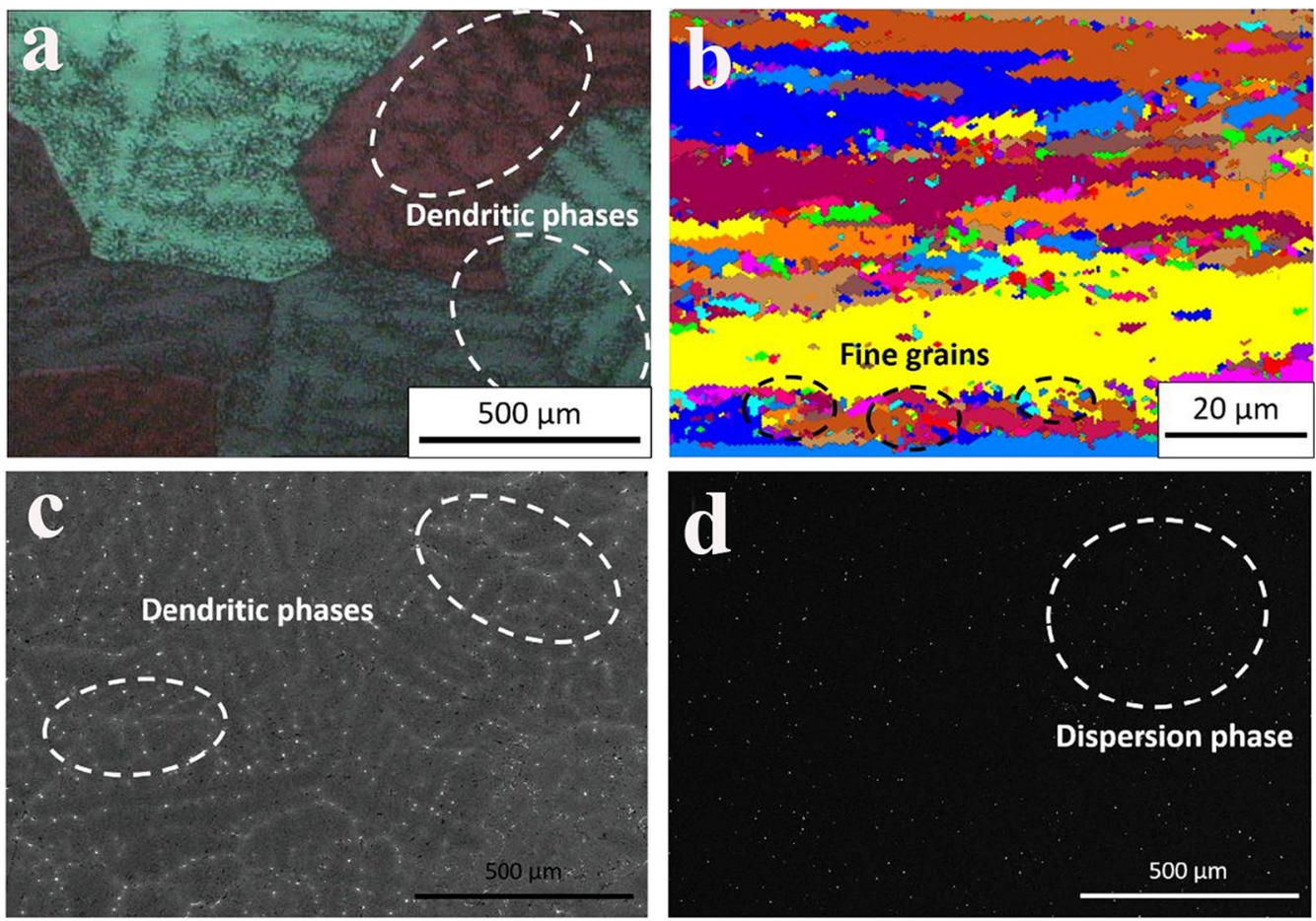

Fig. 8 Electron backscattered diffraction and backscattered electron image analyses of the as-cast and as-rolled $\mathrm{Al}-0.5 \mathrm{Mg}-0.1 \mathrm{Sn}-0.05 \mathrm{Ga}-0.05 \mathrm{In}$ alloys: a, c the as-cast, b, d the as-rolled. Reproduced with permission from Ref.[74]. Copyright 2017, The Authors

using a processing technology to re-integrate the Al alloy structure were proposed.

In terms of activation, the alloy element is attached to the surface of the Al matrix through the process of dissolution-redeposition, forming active sites to destroy the surface oxide film. The activation effect of the multi-element "eutectic" mechanism outweighs that of the one-element "dissolution-redeposition" mechanism. Performance of alloy elements can be reinforced by proper amount of precipitation, whereas exceeding precipitates can trigger severe corrosion that induces degraded electrochemical performance of the alloy. Post-process technology, such as the rolling process, can further activate the alloy and avoid severe corrosion because it can promote the even distribution of precipitated phases on the entire surface of the alloy in the form of dispersed phases instead of segregated phases.

As for the corrosion inhibition of $\mathrm{Al}$ alloy, adding elements with high hydrogen evolution overpotential is a preferred method. In addition, these types of elements have good corrosion inhibition effect via (1) stabilizing the $\mathrm{Al}$ oxide film; (2) forming a new oxide film; (3) possessing more negative potential than $\mathrm{Al}$; (4) improving the alloy's tolerance for impurities. It should be noted that the content of alloy elements should be elaborately considered since the exceeded amount will increase the self-corrosion. Meltspinning makes the alloy elements to form a supersaturated solid solution to solve this problem.
In summary, activating the alloy and suppressing the selfcorrosion at the same time seem to be difficult at the moment. To realize this goal, we here propose some suggestions: (1) The electrolyte is a very important component that should be elaborately designed to realize high efficient aqueous $\mathrm{Al}$-air battery. Not only the selection of appropriate elements and quantities but also the corrosion inhibitor additives and new electrolyte systems (i.e., aqueous concentrated electrolyte) are urgently required to modify the electrode/electrolyte interface synergistically; (2) Exact activation and corrosion inhibition mechanisms are also imperative to be revealed to guide the development of $\mathrm{Al}$ alloys correctly; (3) Reasonable design of $\mathrm{Al}$ alloy electrode and battery structures is another direction to promote the electrochemical performance and application of aqueous $\mathrm{Al}$-air batteries.

Acknowledgements This work was financially supported by the National Nature Science Foundation of China (Nos. 21975289, 21905306 and U19A2019), the Hunan Provincial Science and Technology Plan Project, China (Nos. 2017TP1001 and2018RS3009), the Key Areas Research and Development Plan of Hunan Province (No. 2019GK2033), the Key-Area Research and Development Program of Guangdong Province (No. 2020B090919001). 


\section{References}

[1] B. Xu, S. Qi, M. Jin, X. Cai, L. Lai, Z. Sun, X. Han, Z. Lin, H. Shao, P. Peng, Z. Xiang, J.E. Ten Elshof, R. Tan, C. Liu, Z. Zhang, X. Duan, J. Ma, Chin. Chem. Lett. 30, 2053 (2019)

[2] R. Rajagopalan, Y. Tang, X. Ji, C. Jia, H. Wang, Adv. Funct. Mater. 30, 1909486 (2020)

[3] Z. Wei, B. Ding, H. Dou, J. Gascon, X. Kong, Y. Xiong, B. Cai, R. Zhang, Y. Zhou, M. Long, J. Miao, Y. Dou, D. Yuan, J. Mater. Chin. Chem. Lett. 30, 2110 (2019)

[4] H. Wang, D.Y.C. Leung, M.K.H. Leung, Appl. Energy 90, 100 (2012)

[5] C.T. Driscoll, W.D. Schecher, Environ. Geochem. Health 12, 28 (1990)

[6] Y. Li, H. Dai, Chem. Soc. Rev. 43, 5143 (2014)

[7] J. Li, J. Chen, H. Wan, J. Xiao, Y. Tang, M. Liu, H. Wang, Appl. Catal. B 242, 209 (2019)

[8] J. Li, L. Fu, J. Luan, H. Xie, F. Cheng, Y. Tang, H. Wang, J. Electrochem. Soc. 165, A3766 (2018)

[9] H. Abe, Y. Hirai, S. Ikeda, Y. Matsuo, H. Yabu, NPG Asia Mater. 11, 1 (2019)

[10] H. Jin, C. Guo, X. Liu, J. Liu, A. Vasileff, Y. Jiao, Y. Zheng, S. Qiao, Chem. Rev. 118, 6337 (2018)

[11] F. Li, J. Li, Q. Feng, J. Yan, Y. Tang, H. Wang, J. Energy Chem. 27, 419 (2018)

[12] Y. Wang, J. Hao, J. Yu, H. Yu, K. Wang, X. Yang, J. Li, W. Li, J. Energy Chem. 45, 119 (2020)

[13] M. Jiang, C. Fu, J. Yang, Q. Liu, J. Zhang, B. Sun, Energy Storage Mater. 18, 34 (2018)

[14] Q. Kang, T. Zhang, X. Wang, Y. Wang, X. Zhang, J. Power Sources 443, 227251 (2019)

[15] H. Jiang, S. Yu, W. Li, Y. Yang, L. Yang, Z. Zhang, J. Power Sources 448, 227460 (2020)

[16] H. Zhou, Z. Qian, M. Zhou, X. Liu, Y. Li, X. Zhang, Acta Metall. Sin. Engl. Lett. 33, 659 (2020)

[17] K.A. Yasakau, J. Tedim, M.L. Zheludkevich, R. Drumm, M. Shem, M. Wittmar, M. Veith, M.G.S. Ferreira, Corros. Sci. 58, $41(2012)$

[18] M.A. Deyab, Electrochim. Acta 244, 178 (2017)

[19] S. Wu, Q. Zhang, D. Sun, J. Luan, H. Shi, S. Hu, Y. Tang, H. Wang, Chem. Eng. J. 383, 123162 (2020)

[20] Y. Liu, H. Zhang, Y. Liu, J. Li, W. Li, J. Power Sources 434, 226723 (2019)

[21] E. Grishina, D. Gelman, S. Belopukhov, D. Starosvetsky, A. Groysman, Y. Ein-Eli, Chemsuschem 9, 2103 (2016)

[22] D. Wang, D. Zhang, K. Lee, L. Gao, J. Power Sources 297, 464 (2015)

[23] P. Katsoufis, V. Mylona, C. Politis, G. Avgouropoulos, P. Lianos, J. Power Sources 450, 227624 (2020)

[24] B.J. Hopkins, Y. Shao-Horn, D.P. Hart, Science 362, 658 (2018)

[25] P. Zhang, X. Liu, J. Xue, K. Jiang, J. Power Sources 451, 227806 (2020)

[26] R. Ly, A.I. Karayan, K.T. Hartwig, H. Castaneda, Electrochim. Acta 308, 35 (2019)

[27] R. Liang, Y. Su, X. Sui, D. Gu, G. Huang, Z. Wang, J. Solid State Electrochem. 23, 53 (2019)

[28] P. Goel, D. Dobhal, R.C. Sharma, J. Energy Storage 28, 101287 (2020)

[29] Y. Liu, Q. Sun, W. Li, K.R. Adair, J. Li, X. Sun, Green Energy Environ. 2, 246 (2017)

[30] J. Bernard, M. Chatenet, F. Dalard, Electrochim. Acta 52, 86 (2006)

[31] C. Wang, Y. Yu, J. Niu, Y. Liu, D. Bridges, X. Liu, J. Pooran, Y. Zhang, A. Hu, Appl. Sci. 9, 2787 (2019)

[32] J. Ryu, M. Park, J. Cho, Adv. Mater. 31, e1804784 (2019)
[33] D.M. Dražić, S.K. Zečević, R.T. Atanasoski, A.R. Despić, Electrochim. Acta 28, 751 (1983)

[34] M.C. Reboul, P.H. Gimenez, I.J. Rameau, Corrosion 40, 366 (1984)

[35] Z. Li, L. Yi, Z. Liu, L. Yang, J. Su, Y. Chen, J. Electrochem. 3, $316(2001)$

[36] M. Yang, Y. Liu, Z. Shi, X. Lv, B. Liu, L. Sun, Corrosion 76, 366 (2020)

[37] J. Zhang, M. Klasky, B.C. Letellier, J. Nucl. Mater. 384, 175 (2009)

[38] Z. Wu, H. Zhang, C. Guo, J. Zou, K. Qin, C. Ban, H. Nagaumi, J. Solid State Electrochem. 23, 2483 (2019)

[39] Z. Wu, H. Zhang, K. Qin, J. Zou, K. Qin, C. Ban, J. Cui, H. Nagaumi, J. Mater. Sci. 55, 11545 (2020)

[40] J. Wloka, G. Bürklin, S. Virtanen, Electrochim. Acta 53, 2055 (2007)

[41] X. Gu, J. Zhang, X. Fan, L. Zhang, Acta Metall. Sin. -Engl. Lett. 33, 327 (2020)

[42] J. Chu, T. Lin, G. Wang, H. Fang, D. Wang, Metallogr. Microstruct. Anal. 9, 312 (2020)

[43] J. Hunter, Dissertation (University of Oxford, Oxford, 1989)

[44] J. Ma, J. Wen, J. Gao, Q. Li, Electrochim. Acta 129, 69 (2014)

[45] Z. Wu, H. Zhang, J. Zou, K. Qin, C. Ban, J. Cui, H. Nagaumi, Effect of microstructure on discharge performance of Al-0.8Sn$0.05 \mathrm{Ga}-0.9 \mathrm{Mg}-1.0 \mathrm{Zn}(\mathrm{wt} \%)$ alloy as anode for seawater-activated battery. Mater. Corros. (2020). https://doi.org/10.1002/ maco.202011663

[46] J. Ma, F. Ren, G. Wang, Y. Xiong, Y. Li, J. Wen, Int. J. Hydrog. Energy 42, 11654 (2017)

[47] J. Ma, J. Wen, J. Gao, Q. Li, J. Power Sources 253, 419 (2014)

[48] J. Ren, J. Ma, J. Zhang, C. Fu, B. Sun, J. Alloys Compd. 808, 151708 (2019)

[49] L. Fan, H. Lu, J. Leng, Z. Sun, J. Electrochem. Soc. 162, A2623 (2015)

[50] S. Gudić, J. Radošević, D. Krpan-Lisica, M. Kliškić, Electrochim. Acta 46, 2515 (2001)

[51] D.R. Egan, C. Ponce De León, R.J.K. Wood, R.L. Jones, K.R. Stokes, F.C. Walsh, J. Power Sources 236, 293 (2013)

[52] H. Lee, T.A. Listyawan, N. Park, G. Kim, I. Chang, Int. J. Precis. Eng. Manuf. Green Technol. 7, 505 (2020)

[53] Y. Tang, L. Lu, H.W. Roesky, L. Wang, B. Huang, J. Power Sources 138, 313 (2004)

[54] J.C. Muller, J.R. Galvele, Corros. Sci. 17, 995 (1977)

[55] L. Li, H. Liu, Y. Yan, H. Zhu, H. Fang, X. Luo, Y. Dai, K. Yu, Int. J. Hydrog. Energy 44, 12073 (2019)

[56] D.O. Flamini, S.B. Saidman, Mater. Chem. Phys. 136, 103 (2012)

[57] Z. Sun, H. Lu, L. Fan, Q. Hong, J. Leng, C. Chen, J. Electrochem. Soc. 162, A2116 (2015)

[58] S. Gudić, I. Smoljko, M. Kliškić, J. Alloys Compd. 505, 54 (2010)

[59] J.B. Bessone, D.O. Flamini, S.B. Saidman, Corros. Sci. 47, 95 (2005)

[60] J. Ma, J. Wen, H. Zhu, Q. Li, J. Power Sources 293, 592 (2015)

[61] J. Ma, J. Wen, F. Ren, G. Wang, Y. Xiong, J. Electrochem. Soc. 163, A1759 (2016)

[62] H. Xiong, X. Yin, Y. Yan, Y. Dai, S. Fan, X. Qiao, K. Yu, J. Materi. Eng. Perform. 25, 3456 (2016)

[63] P. Ratchev, B. Verlinden, P. Van Houtte, Acta Metall. Mater. 43, 621 (1995)

[64] T. Xu, Z. Hu, C. Yao, Int. J. Electrochem. Sci. 14, 2606 (2019)

[65] Z. Zhao, X. Chen, M. Hao, Energy 36, 2782 (2011)

[66] Q. Wang, H. Miao, Y. Xue, S. Sun, S. Lia, Z. Liu, RSC Adv. 7, 25838 (2017)

[67] J.C. Walmsley, Ø. Sævik, B. Graver, R.H. Mathiesen, Y. Yu, K. Nisancioglu, J. Electrochem. Soc. 154, C28 (2007)

[68] H. Moghanni-Bavil-Olyaei, J. Arjomandi, M. Hosseini, J. Alloys Compd. 695, 2637 (2017) 
[69] K. Kurt, S. Diplas, J.C. Walmsley, K. Nisancioglu, J. Electrochem. Soc. 160, C542 (2013)

[70] E. Senel, K. Nisancioglu, Corros. Sci. 131, 330 (2018)

[71] F. Eckermann, T. Suter, P.J. Uggowitzer, A. Afseth, P. Schmutz, Electrochim. Acta 54, 844 (2008)

[72] P. Zhang, X. Liu, J. Xue, Z. Wang, J. Mater. Eng. Perform. 28, $5476(2019)$
[73] M.R. Sovizi, M. Afshari, K. Jafarzadeh, J. Neshati, Ionics 23, $3073(2017)$

[74] X. Yin, K. Yu, T. Zhang, H. Fang, H. Dai, H. Xiong, Y. Dai, Int. J. Electrochem. Sci. 12, 4150 (2017)

[75] L. Fan, H. Lu, J. Leng, Electrochim. Acta 165, 22 (2015) 